\title{
POSSIBILITIES OF ADAPTING THE TYPOLOGIES OF THE INTERNATIONAL STANDARDS FOR ESTABLISHING CRIMINAL LIABILITY FOR CORRUPTION-RELATED CRIMES IN UKRAINE
}

\author{
Ruslan Orlovskyi \\ Yaroslav Mudryi National Law University, Kharkiv, Ukraine \\ Roman Shapoval \\ Yaroslav Mudryi National Law University, Kharkiv, Ukraine
}

Olga Demenko

Simon Kuznets Kharkiv National University of Economics, Kharkiv, Ukraine

\begin{abstract}
The article validates the relevance of the implementation of international standards in the national anti-corruption policy, taking into account the progressive and sustainable development of corrupt practices in Ukraine. The purpose of the research is to propose a structural and functional algorithm for improving the process of establishing criminal liability for corruption-related crimes following international anti-corruption standards using the method of structural and functional modeling. The level of implementation and compliance of national legislation with international standards for combating corruption was assessed, which allowed identifying conflicts in legislative and normative acts on the formation of the list of corruption crimes and the procedures used for their investigations by type of legal responsibility. The article presents a structural and logical algorithm for the implementation of international standards in determining criminal liability for corruption-related offenses in Ukraine.
\end{abstract}

Keywords: International anti-corruption conventions, Criminal liability, Corruption investigation procedures, Anti-corruption policy.

DOI: http://dx.doi.org/10.15549/jeecar.v5i2.230

\section{INTRODUCTION}

In modern conditions of social and economic development of Ukraine, corruption has become part of the state and social mechanism. It unifies the methods and forms of relations of state authorities with representatives of legal business and organized criminality and integrates them into a single system of shadow (criminal) relations. As recently as 2015 the Bloomberg analysts ranked Ukraine the second in the rating for the Global Multidimensional Poverty Index, based on indicators of inflation and unemployment. According to Bloomberg financial analysts' data given in the Global Risk Briefing, in 2017 inflation in Ukraine exceeded the $10 \%$ mark, and the unemployment rate was above 8.8\%. (Bloomberg, 2016). One of the 
leading international auditing companies, Ernst \& Young, ranked Ukraine first among the 41 countries in Europe, the Middle East, India and Africa (EMEIA) by the level of corruption in business following the results of their research in 2017. Regarding these indicators, Ukraine belongs to the countries of "high risk," the forming factor of which is the shadow economy, provoked by a significant level of corruption in the state (Europe, Middle East, India and Africa Fraud Survey, 2017).

Ukraine's pursuance of European standards makes it necessary to overcome such a negative phenomenon as corruption and necessitates the implementation of international standards in the national legislation and practical anticorruption activities. Certain positive trends and shifts can be observed in the administrative and legal regulation of the anti-corruption system. Since 2014, of the creation of a significant number of anti-corruption bodies, the adoption of new anti-corruption regulatory and legal acts, and the expansion of the parameters of freedom of speech and the press, in Ukraine the level of corruption perception by business decreased from 99\% to 96\% in 2015-2017 (Corruption Perceptions Index, 2018). Nevertheless, the status of corruption in the state exceeds the threshold called "shame of the nation." First of all, this is determined by the ineffectiveness of procedures for investigating corruption offenses and flaws in the regulatory legislation. In this regard, the issue of the argumentation of approaches to adjusting the classification of corruption-related offenses by criminal liability is being updated on the basis of bringing national legislation in line with international European standards.

\section{METHODOLOGICAL OF THE RESEARCH}

\section{International Assessment of the Level of} Corruption in Ukraine

According to Transparency International, in 2017 Ukraine ranked $130^{\text {th }}$ out of 180 countries in the "Corruption Perceptions Index" rating. Based on the findings of experts, a decrease in the CPI evaluation by only one point provokes an outflow of capital from a country that equates to $0.5 \%$ of the state's GDP. For Ukraine, these figures mean a loss of at least UAH 20 billion annually. Undoubtedly, Ukraine improved its CPI position in 2017 compared to
2013 by 14 points but remains at a very low level (Corruption Perceptions Index, 2018). In addition, until the year 2015 Ukraine occupied the lowest position regarding CPI scores, yielding to the least developed countries and low- and middle-income countries. Since 2015, the situation has somewhat improved and by 2017 Ukraine has surpassed these categories of countries (Corruption Perceptions Index, 2018).

The Corruption Index of the International Country Risk Guide (ICRG) also confirms that corruption is much more entrenched in Ukraine than in other low- and middle-income countries. The gap is even more frustrating when comparing Ukraine with the countries of Central, Eastern, and South-Eastern Europe and, especially, with the EU countries (Political Risk Services: International Country Risk Guide, 2018).

By the Control of Corruption Indicator, calculated by a series of the World Bank quality indicators, during 1998-2016 Ukraine is characterized by a high level of the use of state power in personal interests and the absorption of the state by elites. The indicator value varied from a minimum of -1.27 (1998) to a maximum of 0.72 (2005) for Ukraine over this period was from (Worldwide Governance Indicators, 2018). In 2017 its value was determined as -0.98 . The Control of Corruption Indicator ranges from -2.5 to +2.5 (the lower value indicates higher corruption). It is constructed by combining key data from several sources.

Also, the high level of corruption in Ukraine is a significant obstacle to the development of business in the country, as the data determine corruption as the most problematic and sustainable factor for doing business (The Global Competitiveness Report 2014-2015, 2014; The Global Competitiveness Report 2017-2018, 2017).

The data of the latest survey of enterprises by the World Bank, which are collected every 3-4 years by interviewing business owners and top managers of private companies, indicate that Ukraine is the world's leader in bribery and exceeds this average world index by more than twice (Corruption. Enterprise Surveys, 2018). This indicator shows the scope of bribery, that is, the percentage of companies that have satisfied at least one demand for bribes. 


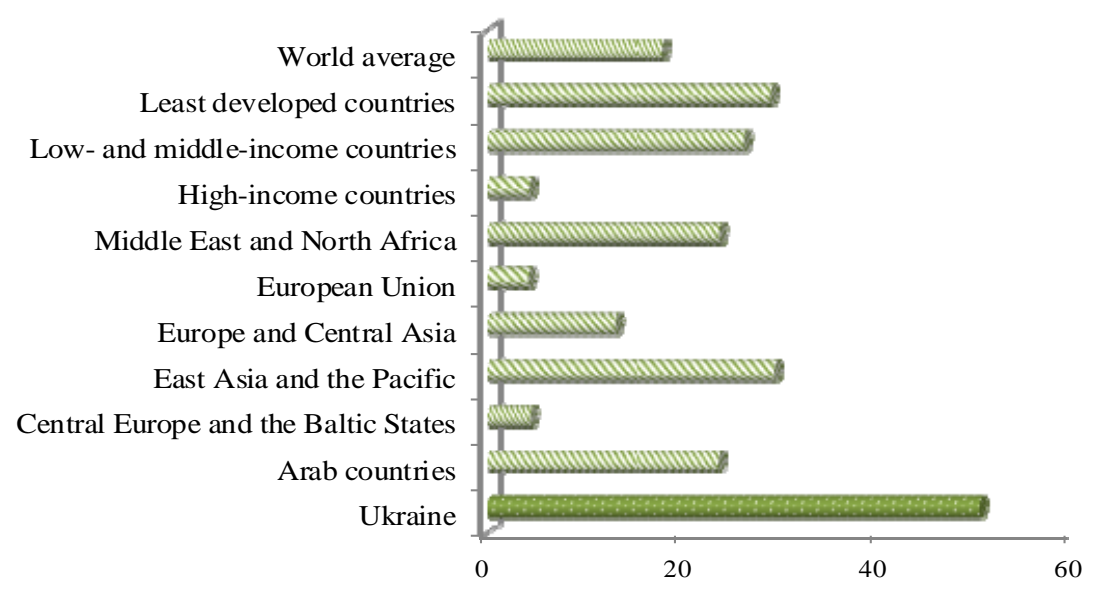

Figure 1. Bribery Index (\% of companies that took bribe at least once) in 2013-2016

Corruption also exerts a significant destructive impact on the economic development of Ukraine. The quadratic regression line indicates that higher values of the Corruption Perceptions Index (indicating a lower level of corruption in the country) associated with a high level of GDP per capita. Ukraine's position above the regression line confirms that Ukraine has a high level of corruption, taking into account its GDP per capita. The coefficient of correlation between GDP per capita and the Corruption Perceptions Index was 0.81 for Ukraine as of 2017 (GDP per capita, 2017; Corruption Perceptions Index, 2018).

Thus, all data sources point to a reasonably consistent picture and confirm the presence of corruption in Ukraine as a global problem requiring urgent proper resolution (Figure 1). The level of corruption in Ukraine is extremely high, which significantly undermines the prospects for economic growth, as it forms obstacles to the inflow of private investment. Moreover, in modern conditions, the reduction of the level of corruption is significant for speeding up the process of rapprochement with other European countries.

It should be noted that in the aftermath of globalization, corruption has ceased to be a problem for only individual states in the world and, since the 1990s, anti-corruption instruments of a transnational nature have been applied. Therefore, in addition to national anticorruption organizations and state bodies, the UN, the World Bank, the Transparency International, the Group of States against Corruption (GRECO), the European Union and others deal with corruption problems
(Ouédraogo, 2017; Loughman \& Sibery, 2012; Arnone \& Borlini, 2014).

In this regard, currently, Ukraine is a party to the list of binding treaties and conventions. In the field of preventing and combating corruption, Ukraine closely cooperates with the Organization for Economic Cooperation and Development (OECD). In the framework of working with the OECD in 2003, the representatives of the governmental delegations of Azerbaijan, Armenia, Georgia, the Russian Federation, Tajikistan, and Ukraine endorsed the Istanbul Anti-Corruption Action Plan of the OECD Anti-Corruption Network for Eastern Europe and Central Asia (Istanbul AntiCorruption Action Plan, 2014).

Since January 1, 2006, Ukraine has become a member of the Council of Europe's Group of States against Corruption (GRECO) in connection with the enforcement of the COE Civil Law Convention on Corruption for Ukraine. Anticorruption standards of the Council of Europe are based on three legislative acts: the Criminal Law Convention on Corruption (ETS 173) (Criminal Law Convention on Corruption, 1999), the Civil Law Convention on Corruption (ETS 174) (Civil Law Convention on Corruption, 1999), and the Additional Protocol to the ETS 173 (Additional Protocol to the Criminal Law Convention on Corruption, 2003). Their objective is to reinforce criminal liability for active and passive bribery of arbitrators and jury members.

To achieve this objective, it is necessary to bring the provisions of the national legislation in compliance with international standards in 
the field of preventing and combating corruption.

After the adoption of a package of progressive anti-corruption laws for 2015-2017 in 2014 by the Parliament of Ukraine, it was possible to achieve significant changes - useful results in the implementation of international standards in this area. However, meanwhile, there remains a high percentage of Ukraine's non-compliance with the recommendations of international organizations to the anti-corruption policy on the implementation of international standards.

The improvement of the penal legislation on liability for corruption crimes is one of the main recommendations unfulfilled by Ukraine, which in turn complicates the corruption investigation process as a factor of a threat to national security, social, economic development, and demoralization of the society. In this regard, this research substantiates the directions for steering the improvement of the process of determining criminal liability for the commission of corruption-related offenses in the framework of the implementation of international standards.

\section{Shortcomings of classification aspects of corruption crimes as a destructive factor of the implementation of international standards}

Ukraine strives to implement international standards into its anti-corruption system. But first of all, it is necessary to determine where and to what extent national legislation fails to meet the standards of international conventions. The analysis shows that the formation of a list of corruption crimes is the main problem of non-compliance with international standards of Ukraine's modern anti-corruption policy, that is, a distinct classification of corruption offenses by the type of legal liability for their commission is required for correct incrimination of the offense and the qualitative operation of the anti-corruption infrastructure.

The establishment of specialized anticorruption bodies according to the recommendations of the OECD (Recommendation 1.6) and GRECO (Recommendation I) for 2015-2017 was a significant achievement in the process of implementing international standards in Ukraine (Anti-Corruption Reforms in Ukraine, 2015).
National Agency on Corruption Prevention as a preventive anti-corruption body having no law enforcement functions;

- National Agency of Ukraine for finding, tracking, and management of assets derived from corruption and other crimes (or Asset Recovery and Management Agency);

- National Anti-Corruption Bureau of Ukraine to investigate exceptionally grave corruption-related offenses;

- Specialized Anti-Corruption Prosecutor's Office to support public prosecution in courts;

- Anti-Corruption Courts for considering the cases dealt with by the Specialized AntiCorruption Prosecutor's Office;

- It should be noted that today, even in the conditions of the formed anti-corruption infrastructure in Ukraine, anti-corruption state bodies are characterized by duplication of functions, lack of proper interaction and coordination of activities.

In 2018, Ukrainian Parliament adopted the law based on the recommendations of the OECD (Ukraine - Opinion on the Draft Law on Anticorruption Courts and on the Draft Law on Amendments to the Law on the Judicial System and the Status of Judges (concerning the introduction of mandatory specialization of judges on the consideration of corruption and corruption-related offences). Also, in 2017, Parliament voted the Draft Law on the establishment of the Supreme Anti-Corruption Court (Draft Law No. 7440, 2018), and the Law "On the Supreme Anti-Corruption Court" (Law of Ukraine No. 2447-VIII, 2018). The new court must administer justice as a court of the first instance in cases determined by procedural law, as well as study and summarize the legal precedents of the relevant categories of corruption-related offenses. The need to attract specialists with international experience is a vital distinction between this state body. However, at the same time, the importance of the Public Council of International Experts is minimized to the Public Council of Virtue - a collection of information about candidates and advisory functions. Also, their decision can be canceled by a decision of the High Qualification Commission - by 11 votes out of 16 . 
It should also be noted that the Supreme AntiCorruption Court of Ukraine is recognized as an indicted body, which negates the effectiveness of its work.

Based on the preceding, it can be concluded that in modern conditions, the effectiveness of institutionalization in the fight against corruption can only be achieved through the strict and independent distribution of functional powers, the formation of a legislative base for qualitative staffing with the involvement of international experts.

Investigators and prosecutors responsible for the application of legal norms analyze and compare the circumstances of the committed offense, after which they determine the relevant article of the crime incrimination. The qualification of corruption offenses should be based on a reliable congruency of the circumstances of the acts committed with the constituent elements of the crime, regulated by the national legislation. A clear and comprehensive list of corruption offenses facilitates an effective investigation and countering corruption in any country (Liu, 2016; Lane, 2017; Boersma, 2012).

During 2014-2017 as a result of the repeated introduction of amendments in the CCU, it was partially possible to bring the classification list of corruption crimes to compliance in the objective and subjective terms. Thus, Article 210 of the Criminal Code of Ukraine (Criminal Code of Ukraine, 2001) refers the misuse of budgetary funds, budget expenditures or provision of loans from the budget without established budget assignments or exceeding them in violation of this Code to corruption offense. According to Article 19, these offenses include:

- embezzlement, waste or misappropriation of property by the abuse of official position; Article 262 qualifies larceny, embezzlement, extortion of firearms, ammunition, explosives or radioactive materials or misappropriation thereof through the abuse of office;

- Article 357 attributes larceny, embezzlement, extortion of documents, stamps, seals, misappropriation thereof through the abuse of office; Article 354 defines bribery of an employee of an enterprise, institution or organization as a corruption offense;
- in Article 364 it is the abuse of power or official position;

- Article 268-2 considers it to be illegal enrichment and Article 369 - proposal, promise or provision of improper advantage to an official under the UN Convention 1 and the UN Convention 2 (United Nations Convention against Corruption, 2003; United Nations Convention against Transnational Organized Crime and the Protocols Thereto, 2004; Criminal Law Convention on Corruption, 1999; Civil Law Convention on Corruption, 1999).

Meanwhile, thus far there are some contradictory aspects in the classification of corruption crimes in the Ukrainian legislative framework, caused by the inconsistency of the concepts of corruption and corruption offense defined in article 1 of the Law "On Prevention of Corruption" (Law of Ukraine "On Prevention of Corruption, 2014) from the position of the act and its purpose.

According to article 45 of the Criminal Code of Ukraine (Criminal Code of Ukraine, 2001), the crimes stipulated in the articles 191, 262, 308, $312,313,320,357,410$, as well as crimes provided for in articles 210, 354, 364, 364, 365 and 368 - 369 of this Code (Criminal Code of Ukraine, 2001) are considered to be corruption, if committed by way of abuse of official position. Criminal, disciplinary and/or civil liability is established by the law for the commission of these offenses.

By the Law (Law of Ukraine No. 1698-VII, 2014), integral elements of corruption include, on the one hand, the use of official powers and associated opportunities as a form of the act. It aims to obtain an undue advantage; on the other hand, the provision or promise of the undue advantage as a form of the act with the aim of using office powers and corresponding opportunities. With this in mind, it can be argued that the corruption list of acts in the CCU regulated by the articles mentioned above does not reflect an exhaustive list of corruption crimes. Simple or aggravated offenses of officials should also be attributed to corruption crimes if they are committed intending to obtaining the undue advantage for themselves or in the interests of third parties. Moreover, these involve more than 100 articles in CCU.

Also, the inconsistency of the terminology 
base of the national legislation gives grounds to assert that it is illogical to refer the offenses regulated by Article 210 of the Criminal Code to the corruption ones. The current wording of the articles of the Code does not reflect an undue advantage either as an Act, or as the purpose of an offense, which does not directly entail special legal consequences due to the commission of the specified offenses.

In the course of the research, it was found out that it would be inappropriate to refer the acts provided for in article 320 of the CCU to the corruption offenses, as it regulates acts that may be attributed as intentional, while their consequences are referred to only as careless, that is, in general, these acts are careless. A corruption act is always intentional; it cannot be careless. This refers to a violation of certain rules (rules for sowing or growing opium poppy or cannabis, rules for the production, manufacture, storage, recording, release, distribution, trade, transportation, transfer or use of narcotic drugs, etc.), which in itself is not is a corruption act (Liu, 2016; Igbari, 2016).

The inconsistency of the contents of article 370 of the CCU should be noted regarding the wording of the concepts "entrapment" and "controlled commission" in the aspect of accomplishing corruption acts for which criminal liability is provided for in the national legislation. It can be argued that article 307 of the CCU prohibits the "controlled commission" because it strictly prohibits another, namely: "instigation" to certain acts of another (subordinated) person, to "denounce that person later on" (Criminal Code of Ukraine, 2001).

Corruption crimes can simultaneously act both as disciplinary and as torts. However, modern Ukrainian legislation contains only general provisions on the procedure for compensation of property and moral harm for corruption offenses, therefore, in the process of investigating a corruption crime, it is difficult to identify which torts are considered corruption, and for what corruption offenses the guilty person is arraigned exclusively to a civil charge.

To date, the Criminal Code provides for an almost exhaustive list of crimes that are corruption-related. The Code of Ukraine on Administrative Offenses (Code of Ukraine on Administrative Offenses, 1984) contains Chapter 13-A, which sets out administrative offenses related to corruption. Regarding the same list of corruption offenses, which are the ground for civil liability, the issue remains uncertain. Consequently, there is a theoretical and practical problem with the need to apply civil liability for corruption offenses as an independent type of legal responsibility. After all, such a conclusion can be drawn based on the analysis of the definition of a corruption offense, especially regarding the use of the alternative conjunction "and/or" in it, when indicating civil liability for the aforesaid illegal act.

Thus, it can be affirmed that in the process of considering and investigating corruption offenses, the flaws in the national legislation regarding the completeness of the list of corruption offenses reduce the effectiveness of the crime incrimination.

\section{ANALYSIS OF THE LEGAL PROCESS OF ESTABLISHING CRIMINAL LIABILITY}

Criminal Procedural Code of Ukraine (Criminal Procedural Code of Ukraine, 2012) and the Law "On the National Anti-Corruption Bureau of Ukraine" (Law of Ukraine No. 1698-VII, 2014) provide effective procedures for investigating and prosecuting criminal cases of corruption crimes with criminal liability. They are regulated by Article 19 of the Law "On the National Anti-Corruption Bureau of Ukraine" and the CPC Articles 2971-2975; CPC Articles 154-158; CPC Articles 100, 167-169, 170-175; CPC Article 269-1; CPC Articles 98-100; CPC Articles 468-476; CPC Articles 541-614.

At the same time, this research identified specific legislative and practical problems in the implementation of international standards in the procedures for determining liability for corruption-related crimes in Ukraine.

Various regulations, including Part 2 of Article 6 of the European Convention on Human Rights (European Convention on Human Rights, 2002), Part 1 of article 62 of the Constitution of Ukraine (Constitution of Ukraine, 1996), and article 17 of the Criminal Procedural Code of Ukraine (Criminal Procedural Code of Ukraine, 2012), state that a person is presumed innocent of a criminal offense and cannot be subjected to criminal punishment until his/her guilt is proven.

However, the very fact that the CPC admits an agreement on recognizing guilt with a suspect (and not only with the accused) means that the agreement can be concluded even at the initial 
stage of the investigation. In our opinion, this deficiency is characterized by the fact that at this stage, as a rule, the evidentiary basis for the person's guilt is insufficiently formed, and the guilt of the person who committed the offense has not yet been proven. Besides, the law does not require a prosecutor to apply all the materials of the procedure by the defense team (Criminal Procedural Code of Ukraine, 2012, Art. 221).

Also, at the stage of recognition of suspicion, there is a danger of incorrect legal qualification of the act. This is a corruption risk or the risk of another misuse of office: the act is labelled instead as the divulgence of state secrets (article 328) than as a treason against the State (article 111), preferably as the usurpation of power (article 356) than as extortion of undue advantage (Part 3 of Article 368), etc. (Criminal Procedural Code of Ukraine, 2012).

European Convention on Human Rights in many cases against Ukraine has established the problem of manipulating the labeling process by the prosecution, in particular, to circumvent the requirement of mandatory participation of the defender (European Convention on Human Rights, 2002). Therefore, in these cases, the court must fulfill its obligations stipulated in Part 7 of the CPC Article 474. Such cases of manipulation may take place in practice for the purpose of changing the investigative jurisdiction or for the purpose of not applying the provisions of the Criminal Code, resulting from the recognition of the act as a corruption offense with criminal liability regulated by the Note to Article 45 of the Criminal Code, and the like.

Based on the above reasoning, it can be argued that an agreement on the recognition of guilt should be concluded only after the person is charged.

Also, the provision on the mandatory and unconditional recognition of criminal guilt by the suspect (the accused) in the corruption offense that is governed by Part 1 of CPCU article 472 (Criminal Procedural Code of Ukraine, 2012) should be recognized as the Damocles sword. In conjunction with the criminal liability for willful failure to comply with the agreement by the convicted (Criminal Code of Ukraine, 2001, Art. 3891), this provision may put individuals in a desperate situation, including people with a painful fate, for whom it is easier to take the blame upon themselves than to resist arbitrariness.

Therefore, in these cases, the court must fulfill its obligations stipulated in clauses 3-5 of Part 7 of the CPC Article 474.

Additionally, the defect of authority in the National Anti-Corruption Bureau of Ukraine (NABU) to independently withdraw information from communication channels (wire-tapping,) and conduct investigative acts under cover should be recognized as a destructive factor in the corruption investigation procedure.

Today in Ukraine only the Security Service of Ukraine and the National Police have the right to withdraw information from communication channels, and the NABU carries out wiretapping, bugging and interception of telecommunications with the means provided by the Security Service.

Also, within the framework of this research, it was found that a significant drawback of the methodological background for investigating and considering criminal corruption proceedings is associated with the lack of priorities thereof. Concerning the growing scale of corruption in Ukraine, as well as the existing apparent limitations of labor and financial resources in the process of investigating these offenses, it is advisable to develop a system for prioritizing corruption cases with criminal liability for investigation and prosecution purposes.

For these reasons, it is essential to improve the classification of corruption offenses and the administrative and legal procedures for investigation thereof.

\section{DISCUSSION}

The performance of any system, including the judicial one, is determined by its compliance with national priorities. Therefore, the priority in consideration of corruption crimes should be correlated with national priorities.

According to the Constitution of Ukraine (Constitution of Ukraine, 1996), individuals, their life, and health, honor, and dignity, inviolability and security are recognized as the highest social value. Human rights and freedoms and their guarantees determine the essence and orientation of the State's activity. Therefore, to affirm and ensure human rights and freedoms, to preserve human life and health is the primary national priority. Other national 
priorities of the State include: preservation and augmentation of spiritual, moral and ethical, cultural, historical, intellectual and material values of society, protection of information and natural environment and natural resources; preservation of the constitutional order, sovereignty, territorial integrity of the state (Law of Ukraine No. 964-VI, 2003, Art. 351).

To protect the traditional national values, the level of compliance with national priorities, the key of which is to protect human rights and freedoms, should be the primary criterion for prioritizing criminal cases related to the investigation of corruption crimes.

The seriousness of the corruption offense (the 2nd priority criterion) is intimately connected with the criterion of the level of compliance with national priorities. According to this criterion, first of all, severe and very serious cases that pose a danger to people's lives, leading to loss of efficiency, mental or other health disorders, to the death of the victim are considered first of all (Criminal Code of Ukraine, 2001).

The criterion of "the high profile cases, the participation of high-ranking officials" should be the third priority criterion. Corruption is a public problem and, according to opinion polls, it is one of the most popular and topical in society at present. To eradicate this problem in society, the investigation of corruption must first of all be conducted in the very high profile cases and those with the participation of highranking officials. The investigation of such cases will publicly demonstrate the fight against corruption in the country and the independence of the judiciary bodies, which will help reduce the level of corruption.
The prevalence of the type of corruption is the next most important criterion. In Ukraine, according to the opinion poll, cases involving corruption in the judicial system, law enforcement agencies, medicine, and the political sphere are the most frequent and widespread (Zero success. Corruption after Maidan, 2016). They are prioritized in the investigation.

The possibility of a precedent is a significant criterion in investigating corruption cases. Repetitive crimes, generating new similar ones, which have the highest priority during the consideration, pose the most significant threat to the stability in the country.

The United Nations Handbook on PracticalAnticorruption Measures for Prosecutors and Investigators (UN Handbook on PracticalAnticorruption Measures for Prosecutors and Investigators, 2004) emphasizes another criterion: economic efficiency. Consideration of corruption cases should be based on their economic efficiency: in the process of investigation and following a court order, large amounts of money that have been illegally appropriated as a result of committing a corruption offense shall be returned. This criterion is the least significant among the indicated ones and should be used in case of equality of the others.

Taking into account the corruption problem in Ukraine, Ukrainian legislation and the implementation of international anti-corruption standards, it is possible to formulate criteria for prioritizing corrupt cases subject to litigation (Figure 2).

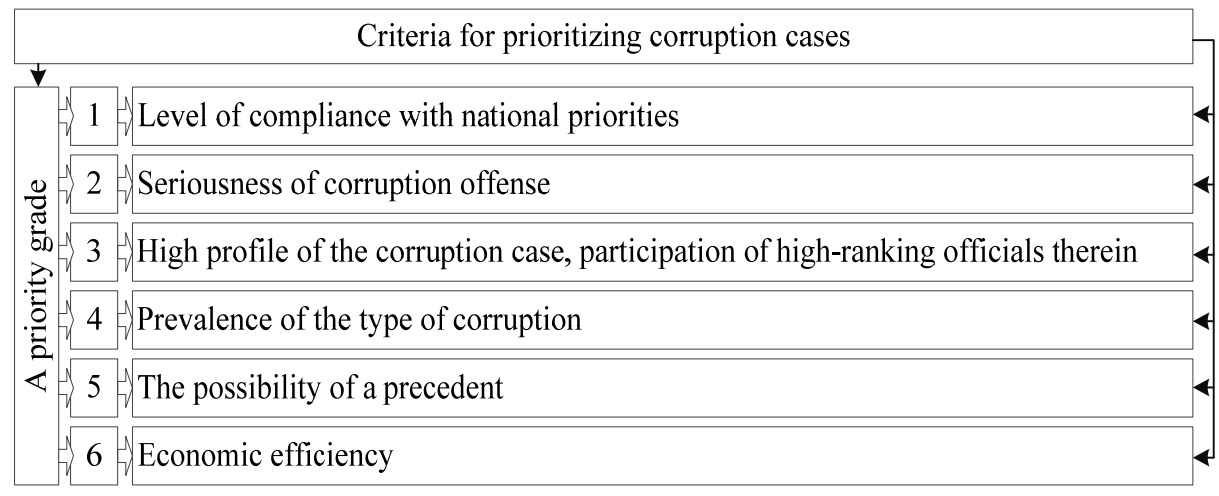

Figure 2. Criteria for prioritizing corruption cases subject to litigation in the process of investigating and considering criminal proceedings in corruption offenses 
Setting priorities when considering with corruption cases will improve the level of citizens' trust in government, reduce the level of corruption, thereby ensuring the maximum effectiveness of the judicial system of Ukraine, with the current time, material and labor constraints.

\section{CONCLUSION AND FURTHER RESEARCH}

The results of the empirical study enabled to draw the following conclusions:

1. Increasingly, they squeeze out the legal and ethical relations between people, gradually turn into a norm of behavior and institutionalize in legislative, organizational, regulatory and administrative form. Moreover, the further spread of corruption in Ukraine poses a threat to its democratic development, constitutional structure, undermines the authority of the state on the international arena, thus creating an immediate threat to national security.

2. The lack of a unified wording of the concepts of "corruption" and "corruption offense" from the position of determining the form of a corruption act and its purpose in national legislation entails difficulties in determining the type of liability for a corruption offense and its incrimination in the investigation process. Substantiation of the need to classify simple or aggravated offenses committed by public officers as corrupt crimes, if the purpose of committing thereof was to obtain an undue advantage; of the legality of a controlled corruption; of introduction of civil liability for corruption offenses allowed improving the classification list of corruption crimes in accordance with international standards.

3. Based on the identified shortcomings in the process of determining criminal liability for corruption crimes enabled to develop a structural and logical algorithm for the implementation of international standards in the legal procedures for investigating corruption. This algorithm is based on the consistency of the concepts of "corruption" and "corruption offense", clarifying the list of corruption crimes with criminal and civil liability, authorizing the NABU to independently withdraw information communication channels (wire-tapping,) and conduct investigative acts under cover; and developed priority ranking of corruption crimes consideration. Such an approach will make it possible to formulate scientific conclusions useful for Ukrainian anti-corruption practice and to achieve compliance with international standards, which will result in the elimination of the conflicts of the national regulatory framework.

\section{REFERENCES}

Additional Protocol to the Criminal Law Convention on Corruption. (2003, May 15). Council of Europe. Retrieved on June 20, 2018, from

https://www.coe.int/en/web/conventions/fu ll-list//conventions/treaty/191?_coeconventions_ WAR_coeconventionsportlet_languageId=en GB

Anti-Corruption Reforms in Ukraine. Round 3 Monitoring of the Istanbul Anti-Corruption Action Plan. (2015, March 24). Organization for Economic Cooperation and Development. Retrieved on June 20, 2018, from https://www.oecd.org/daf/antibribery/Ukraine-Round-3-MonitoringReport-ENG.pdf

Arnone, M., \& Borlini, L.S. (2014). Corruption: Economic Analysis and International Law. Northampton: Edward Elgar.

Bloomberg, Ukraine to remain in the top five most "unfortunate" economies of the world. (2016, February 4). UNIAN Information Agency. Retrieved on April 5, 2018, from https://economics.unian.net/finance/125600 8-ukraina-ostanetsya-v-pyaterke-samyihneschastnyih-ekonomik-mirabloomberg.html

Boersma, M. (2012). Corruption: a violation of human rights and a crime under international law? United Kingdom: Cambridge.

Civil Code of Ukraine. (2003, January 16). The Verkhovna Rada of Ukraine. Retrieved on April 6, 2018, from https://i.factor.ua/law$53 /$

Civil Law Convention on Corruption. (1999, November 4). Council of Europe. Retrieved on April 6, 2018, from https://www.coe.int/en/web/conventions/fu ll-list/-/conventions/treaty/174

Code of Ukraine on Administrative Offenses. (1984, December 7). The Verkhovna Rada of 
Ukraine. Retrieved on April 6, 2018, from https://i.factor.ua/law-41/

Constitution of Ukraine. (1996, June 28). The Verkhovna Rada of Ukraine. Retrieved on April 6, 2018, from http://zakon5.rada.gov.ua/laws/show/254\% D0\%BA/96-\%D0\%B2\%D1\%80

Corruption Perceptions Index. (2018). Transparency International. Retrieved on April 5, 2018, from https://www.transparency.org/research/cpi/ overview

Corruption. Enterprise Surveys. (2018). The World Bank Group. Retrieved on April 5, 2018, from

http://www.enterprisesurveys.org/data/expl oretopics/corruption

Criminal Code of Ukraine. (2001, April 5). The Verkhovna Rada of Ukraine. Retrieved on April 6, 2018, from https://online.zakon.kz/document/?doc_id= 30418109\#pos $=0 ; 0$

Criminal Law Convention on Corruption. (1999, January 27). Council of Europe. Retrieved on April 6, 2018, from

https://www.coe.int/en/web/conventions/fu ll-list/-/conventions/treaty/173

Criminal Procedural Code of Ukraine. (2012, April 13). The Verkhovna Rada of Ukraine. Retrieved on April 6, 2018, from http://www.iuaj.net/node/1099

Draft law No. 4812. "On amending some regulatory acts of Ukraine as to the activity of the National Anti-Corruption Bureau of Ukraine." (2016, June 14). The Verkhovna Rada of Ukraine. Retrieved on April 6, 2018, from

http://search.ligazakon.ua/l_doc2.nsf/link1/J H3PO00I.html

Draft Law No. 7440 "On the establishment of the Supreme Anti-Corruption Court." (2018, June 19). The Verkhovna Rada of Ukraine. Retrieved on June 21, 2018, from http://w1.c1.rada.gov.ua/pls/zweb2/webpro c4_1?pf3511=64248

Europe, Middle East, India, and Africa Fraud Survey. Which do you trust most in the fight against fraud and corruption? (2017).

Retrieved on April 6, 2018, from http://www.ey.com/Publication/vwLUAssets /EY_-_EMEIA_Fraud_Survey_2017/\$FILE/eyemeia-fraud-survey-2017.pdf

European Convention on Human Rights. (2002, May 3). European Court of Human Rights. Retrieved on April 6, 2018, from
https://www.echr.coe.int/Documents/Conve ntion_ENG.pdf

Explanatory Report to the Criminal Law

Convention on Corruption. (1999).

Committee on Corruption Prevention and Counteraction. Retrieved on April 6, 2018, from http://crimecor.rada.gov.ua

GDP per capita. (2017). International Monetary Fund. Retrieved on April 5, 2018, from https://www.imf.org/external/datamapper/ NGDPDPC@WEO/OEMDC/ADVEC/WEOWOR LD

Istanbul Anti-Corruption Action Plan. Manual for Monitoring Experts. (2014). Organization for Economic Cooperation and

Development. Retrieved on April 6, 2018, from http://www.oecd.org/corruption/acn/IAPManual-Monitoring-Experts-RUS.pdf

Law of Ukraine "On the Public Prosecutor's Office." (2015). Vedomosti Verkhovnoy Rady, No. 2-3, Art. 12. Retrieved on April 6, 2018, from https://yuristonline.org/laws/zakon/o_prokurature_2015. pdf

Law of Ukraine No. 1402-VIII "On Judicial System and Status of Judges." (2016). Vedomosti Verkhovnoy Rady, No. 31, Art. 545. Retrieved on April 6, 2018, from http://zakon5.rada.gov.ua/laws/show/140219?test=4/UMfPEGznhhrkf.Zie/j7LbHI4cAs8 0msh8Ie6

Law of Ukraine "On Prevention of Corruption." (2014). Vedomosti Verkhovnoy Rady, No. 49, art. 2056. Retrieved on April 6, 2018, from http://uts.kvsz.com/index.php/novostizakonodatelstva/55-zakon-ukrainy-opredotvrashchenii-korruptsii

Law of Ukraine No. 1698-VII "On the National Anti-Corruption Bureau of Ukraine." (2014). Vedomosti Verkhovnoy Rady, No. 47. Art. 2051. Retrieved on April 6, 2018, from http://kodeksy.com.ua/ka/o_natsionalnom_ antikorruptsionnom_byuro_ukrainy.htm

Law of Ukraine No. 2262-XII "On Pensions for Persons Retired from Military Service and Some Other Persons." (1992). Vedomosti Verkhovnoy Rady, No. 29, Art. 399 with subsequent amendments. Retrieved on April 6, 2018, from http://base.spinform.ru/show_doc.fwx?rgn= 16944

Law of Ukraine No. 2447-VIII "On the Supreme Anti-Corruption Court." (2018, June 7). Vedomosti Verkhovnoy Rady No.24. 
Retrieved on June 21, 2018, from http://zakon5.rada.gov.ua/laws/show/244719/page

Law of Ukraine No. 280-97VR "On Local SelfGovernment in Ukraine." (1997). Vedomosti Verkhovnoy Rady, No. 24, Art. 170.

Retrieved on April 6, 2018, from http://base.spinform.ru/show_doc.fwx?rgn= 12052

Law of Ukraine No. 2911-VI "On Diplomatic Service". (2011). Vedomosti Verkhovnoy Rady, No. 5, Art. 29. Retrieved on April 6, 2018, from http://kodeksy.com.ua/ka/o_diplomatichesk oj_sluzhbe.htm

Law of Ukraine No. 3206-VI "On Principles of Prevention and Counteracting Corruption". (2011). Vedomosti Verkhovnoy Rady, No. 40, Art. 404. Retrieved on April 6, 2018, from http://base.spinform.ru/show_doc.fwx?rgn= 45268

Law of Ukraine No. 889-VIII "On Civil Service". (2016). Vedomosti Verkhovnoy Rady, No. 4, Art. 43. Retrieved on April 6, 2018, from http://base.spinform.ru/show_doc.fwx?rgn= 82374

Law of Ukraine No. 964-VI "On the

Fundamentals of National Security of Ukraine". (2003). Vedomosti Verkhovnoy Rady, No. 39, Art. 351. Retrieved on April 6, 2018, from

http://kodeksy.com.ua/ka/ob_osnovah_naci onalnoj_bezopasnosti_ukrainy.htm

Liu, X. (2016). A Literature Review on the Definition of Corruption and Factors Affecting the Risk of Corruption. Journal of Social Sciences, 4, 6, 171-177.

Loughman, B.P., \& Sibery, R.A. (2012). Bribery and corruption: navigating the global risks. Canada: Ernst \& Yang LLP.

Methodology for Assessing Technical Compliance with the FATF Recommendations and the Effectiveness of AML/CFT systems. (2013). State Financial Monitoring Service of Ukraine. Retrieved on April 6, 2018, from http://www.fatfgafi.org/media/fatf/documents/methodology /FATF\%20Methodology\%2022\%20Feb\%20201 3.pdf

Ouédraogo, I.M. (2017). Governance, Corruption, and the Informal Economy. Modern Economy, 8, 2, 256-271.

Political Risk Services: International Country Risk Guide. (2018). The World Bank Group. Retrieved on April 5, 2018, from https://www.prsgroup.com/explore-ourproducts/international-country-risk-guide/ The Global Competitiveness Report 2014-2015. (2014). World Economic Forum. Retrieved on April 5, 2018, from http://www3.weforum.org/docs/WEF_Globa lCompetitivenessReport_2014-15.pdf

The Global Competitiveness Report 2017-2018. (2017, September 26). World Economic Forum. Retrieved on April 5, 2018, from https://www.weforum.org/reports/theglobal-competitiveness-report-2017-2018

Ukraine - Opinion on the Draft Law on Anticorruption Courts and the Draft Law on Amendments to the Law on the Judicial System and the Status of Judges (concerning the introduction of mandatory specialization of judges on the consideration of corruption and corruption-related offenses). (2017, October 9). Strasburg: European Commission for Democracy through Law (Venice Commission). Retrieved on June 21, 2018, from http://www.venice.coe.int/webforms/docu ments/?pdf=CDL-AD(2017)020-e

Ukraine rose to the first place in the corruption ranking. (2017, April 10 ). Dzerkalo Tyzhnya. Retrieved on April 6, 2018, from https://dt.ua/UKRAINE/ukrayinapidnyalasya-na-perished-miscue-vreytingu-korupciyi-e-y-239238_.html

Ukraine: Letter of Intent, Memorandum of Economic and Financial Policies, and Technical Memorandum of Understanding. (2015, July 21). International Monetary Fund. Retrieved on April 6, 2018, from https://www.imf.org/external/np/loi/2016/u kr/090116.pdf

UN Handbook on Practical-Anticorruption Measures for Prosecutors and Investigators. (2004). United Nations on Drugs and Crime. Retrieved on April 6, 2018, from http://www.unodc.org/pdf/crime/corruptio n/Handbook.pdf

United Nations Convention against Corruption. (2003, October 31). United Nations Office on Drugs and Crime. Retrieved on April 6, 2018, from https://www.unodc.org/unodc/en/treaties/C $\mathrm{AC} /$

United Nations Convention against Transnational Organized Crime and the Protocols Thereto. (2004). United Nations Office on Drugs and Crime. Retrieved on April 6, 2018, from 
https://www.unodc.org/unodc/en/organized -crime/intro/UNTOC.html

Worldwide Governance Indicators. (2018). The World Bank Group. Retrieved on April 5, 2018, from

http://databank.worldbank.org/data/reports. aspx?Report_Name=WGI-

Table\&Id=ceea $4 \mathrm{~d} 8 \mathrm{~b}$

Zero success. Corruption after Maidan. (2016, November 17). Korrespondent.net. Retrieved on April 6, 2018, from https://korrespondent.net/ukraine/politics/3 775556-korruptsyia-v-ukraynevynuzhdeny-yly-sohlasny
ABOUT THE AUTHOR

Ruslan Orlovskyi: innanesk10@gmail.com

Mr. Ruslan Orlovskyi is the Candidate of Legal Sciences and holds the position of Associate Professor at the Department of Criminal Law at the Yaroslav Mudryi National Law University. He is the author of over the 70 publications on crime complicity, the fight against organized crime, and corruption

Dr. Roman Shapoval is the Professor at the Department of Administrative Law and Administrative Activity of Yaroslav Mudryi National Law University. In 2011, Dr. Shapoval defended his dissertation on the topic of "Administrative and Legal Regulation of Educational Activities in Ukraine." In 2014 he was awarded the position of Associate Professor and was promoted to the rank of Professor in 2018. He has published over 50 scientific articles, co-authored four textbooks.

Ms. Olga Demenko is the Candidate of Law Sciences and holds the position of Associate Professor at the Department of Pedagogy and Foreign Philology at the Semen Kuznets Kharkiv National University of Economics. Ms. Demenko has 19 academic publications. 